\title{
Oxidative stress and age-related changes in $T$ cells: is thalassemia a model of accelerated immune system aging?
}

\author{
MAHDI GHATREH-SAMANI ${ }^{1}$, NAFISEH ESMAEILI ${ }^{2}$, MASOUD SOLEIMANI ${ }^{3}$, \\ MAJID ASADI-SAMANI ${ }^{4}$, KEIHAN GHATREH-SAMANI ${ }^{5}$,HEDAYATOLAH SHIRZAD \\ ${ }^{1}$ Medical Plants Research Center, Shahrekord University of Medical Sciences, Shahrekord, Iran \\ ${ }^{2}$ Department of Immunology, School of Medicine, Isfahan University of Medical Sciences, Isfahan, Iran \\ ${ }^{3}$ Department of Hematology, Tarbiat Modares University, Tehran, Iran \\ ${ }^{4}$ Student Research Committee, Shahrekord University of Medical Sciences, Shahrekord, Iran \\ ${ }^{5}$ Clinical Biochemistry Research Center, Shahrekord University of Medical Sciences, Shahrekord, Iran \\ ${ }^{6}$ Cellular and Molecular Research Center, Shahrekord University of Medical Sciences, Shahrekord, Iran
}

\begin{abstract}
Iron overload in $\beta$-thalassemia major occurs mainly due to blood transfusion, an essential treatment for $\beta$-thalassemia major patients, which results in oxidative stress. It has been thought that oxidative stress causes elevation of immune system senescent cells. Under this condition, cells normally enhance in aging, which is referred to as premature immunosenescence. Because there is no animal model for immunosenescence, most knowledge on the immunosenescence pattern is based on induction of immunosenescence. In this review, we describe iron overload and oxidative stress in $\beta$-thalassemia major patients and how they make these patients a suitable human model for immunosenescence. We also consider oxidative stress in some kinds of chronic virus infections, which induce changes in the immune system similar to $\beta$-thalassemia major. In conclusion, a therapeutic approach used to improve the immune system in such chronic virus diseases, may change the immunosenescence state and make life conditions better for $\beta$-thalassemia major patients.
\end{abstract}

Key words: $\beta$-thalassemia major, iron overload, oxidative stress, antioxidant therapy.

(Cent Eur J Immunol 2016; 41 (1): 116-124)

\section{Introduction}

In spite of considerable progress in iron chelating agents, iron overload is still the major cause of death in $\beta$-thalassemia major patients [1]. In addition to blood transfusion, other reasons for iron overload are further iron absorption from the gastrointestinal tract in $\beta$-thalassemia major patients and hemolysis. Excessive iron deposits in visceral organs (mainly in the heart) lead to tissue damage, and organ dysfunction and failure such as cardiac disease, which is the major cause of death in $\beta$-thalassemia major patients [2]. In normal conditions, iron transport in the cells is managed by iron-responsive proteins [3]. Actually, nonheme iron is circulating and is/in a form bound to transferrin that is sensed and internalized by the transferrin receptor (TfR) on the cell surface. TfR is expressed by all iron requiring cells. In an iron overload state, free Fe may exceed iron-binding capacity of transferrin, which leads to unrestrained circulating forms of non-transferrin bound iron (NTBI) $[4,5]$. NTBI is a potentially toxic form of iron as labile iron which transmits into cytosol in a non-regular procedure. It deposits on cell surfaces and/or is excessive- ly taken up by cells in the forms that lead to raising the labile cell iron (LCI). LCI is cell-infiltrating forms of iron which are redox active [6]. Non-transferrin bound iron and transferrin bound iron move to cytosol, but there are no cellular monitored processes for Fe excretion [7]. Better understanding of the mechanism of the immune system in an excessive iron condition in $\beta$-thalassemia major patients and immunological common points between thalassemia and other diseases can increase our knowledge of the immune system behavior in oxidative stress condition. Thus, in the present review, we will discuss the effect of iron overload and oxidative stress conditions on the immune system and then immunological function similarities among aging, chronic virus infection and $\beta$-thalassemia major diseases in humans.

\section{Thalassemia and oxidative stress}

Accumulation of plasma NTBI in $\beta$-thalassemia major correlates with an increase in oxidation products and decrease in antioxidant capacity [8]. Iron is the most abundant transition metal in the periodic table with oxidation

Correspondence: Prof. Hedayatolah Shirzad, Cellular and Molecular Research Center, Shahrekord University of Medical Sciences,

Shahrekord, Iran, e-mail: shirzadeh@yahoo.com

Submitted: 14.05.2015; Accepted: 20.07.2015 
states ranging from $-\mathrm{II}$ to $+\mathrm{VI}$. Iron has two biologically relevant oxidation states, $\mathrm{Fe}^{2+}$ and $\mathrm{Fe}^{3+}$, and electron transfer between $\mathrm{Fe}^{2+}$ and $\mathrm{Fe}^{3+}$. Fe has a vital function in the respiratory chain because of $\mathrm{Fe}$ oxidation state, $\mathrm{Fe}^{2+}$ can be easily oxidized to $\mathrm{Fe}^{3+}$ and reduced back and is involved in essential energy production by many living organisms specially aerobic cells [9]. The redox potential of iron is the main reason for its toxicity. Fe can lead to the Haber Weiss Fenton pattern by engendering the reactive oxygen species (ROS). $\mathrm{Fe}^{2+}$ reduces one electron of dioxygen and leads to superoxide formation, specially hydroxyl radicals [2].

$$
\begin{gathered}
\mathrm{Fe}^{2+}+\mathrm{O}^{2-} \rightarrow \mathrm{Fe}^{3+}+\mathrm{O}^{2-} \\
2 \mathrm{O}^{2-\bullet}+2 \mathrm{H}^{+} \rightarrow \mathrm{H}_{2} \mathrm{O}_{2}+\mathrm{O}_{2} \\
\mathrm{Fe}^{2+}+\mathrm{H}_{2} \mathrm{O}_{2} \rightarrow \mathrm{OH}^{\bullet}+\mathrm{OH}^{-}+\mathrm{Fe}^{3+}
\end{gathered}
$$

Also $\mathrm{Fe}^{2+}$ can catalyze hydrogen peroxide $\left(\mathrm{H}_{2} \mathrm{O}_{2}\right)$ and generate hydroxyl radical, which is the most reactive and damaging intermediate of cellular metabolism. In fact, $\mathrm{Fe}$ is an intrinsic producer of ROS [10]. There are many reasons for iron overload in $\beta$-thalassemia major patients such as macrophage recycling of iron from hemoglobin, excessive iron intake, genetic defect and hemolysis of repeated blood transfusions. Iron overload leads to a rise in LCI and promotes formation of ROS from physiological oxygen intermediates $[5,11,12]$. Indeed enhanced production of ROS increases oxidants/antioxidants activity balance like $\beta$-thalassemia major conditions and disturbs the balance between ROS production and ROS removal, which is called oxidative stress [13]. Certainly, one obvious reason for oxidative stress in $\beta$-thalassemia major is iron overload and the other one is excessive unpaired $\alpha$-hemoglobin chains [14]. It has been found that accumulation and autoxidation of the unpaired $\alpha$-globin chains in severe $\beta$-thalassemia major would generate ROS, superoxide $\left(\mathrm{O}^{2-}\right)$ and $\mathrm{H}_{2} \mathrm{O}_{2}$ that damage cellular proteins, lipids, and nucleic acids. Indeed, free $\alpha$ chains in $\beta$-thalassemia increase autoxidation rates by about twice faster $[15,16]$.

\section{Oxidative stress and immunosenescence}

The general consensus in iron overload condition is cell cycle progression, an elevated physiological level of ROS and oxidative stress condition for a prolonged period, which lead to cell death or cell cycle arrest (senescence) much earlier than the expected Hayflick limit, which has been termed premature senescence [17]. The Hayflick limit is an occurrence that labels potential numbers of proliferation in diploid cells. It has been found that the shortening of telomeres happens in somatic cells with each cell division. Indeed, human somatic cells have limited replicated life duration because telomere erosion leads eventually to cell cycle arrest, aging/senescence, or apoptosis [18, 19].

Many studies have described the variations that occur in senescence cells by oxidative stress condition, including phosphorylation at Ser51 of eIF2 $\alpha$, which plays a major role in translation repression, or damaging cellular components such as DNA, chromatin structure, proteins and lipids [20-22]. The preferential mechanism underlying this aging is DNA damage, which specially accelerates the telomere-shortening rate in oxidative stress condition [23-25]. Actually, some kinds of DNA damage, which do not repair, lead to cellular senescence or cell death, consistent with the findings that DNA repair capacity related to oxidative DNA damage significant downturn in senescent cells [23]. Early inception of cellular senescence, which is caused by oxidative stresses, is termed stress-induced premature senescence (SIPS) [26]. $\mathrm{H}_{2} \mathrm{O}_{2}$ has been the most routinely used inducer of SIPS [27]. Enhancement of $\mathrm{H}_{2} \mathrm{O}_{2}$ induces remarkable telomere shortening and DNA damaging and also leads to cell cycle arrest due to p53-dependent pathway. Indeed, $\mathrm{H}_{2} \mathrm{O}_{2}$ enhances p53 binding activity while the DNA repair capacity does not increase [28, 29]. Circulating iron causes oxidative damage to lymphocyte DNA and has a negative effect on antioxidant defense. Also, it adversely affects immune cell proliferation and function [30, 31]. Like other mitotic cells, T lymphocytes are unable to proliferate when they reach to replicative senescence and gain some functional phenotypes instead [32]. One of the well-known markers of senescence T cells is lack of expression of CD28, the major co-stimulatory receptor. Cell cycle arrest and inexistence of cell surface and mRNA expression of the CD28 co-stimulatory molecule on $\mathrm{T}$ cells have been seen after repeated cell cycles and several rounds of cell division [33]. Replicative senescence of CD8 T cells is also resistant to programmed cell death and a similar finding has been reported for senescent fibroblasts, and permanently loses expression of the CD28 marker [34, 35]. There is a correlation between CD28 and telomerase; the shorter telomeres have been seen in CD28$\mathrm{T}$ cells compared with $\mathrm{CD} 28^{+} \mathrm{T}$ cells. Indeed, $\mathrm{T}$ cells are able to upregulate telomerase during activation and optimal telomerase upregulation in T cells is highly dependent on CD28 signal transduction [36-38]. Telomerase activity requires human telomerase catalytic subunit (hTERT) phosphorylation. TERT is a substrate for Akt in T cells, so the loss of CD28 leads to a decline in Akt phosphorylation, consequently senescence $\mathrm{T}$ cells differentiate from $\mathrm{CD} 28^{+}$ to $\mathrm{CD} 28^{-}$, which could not be reversed $[39,40]$. Besides, hTERT and AKT, and mitogen activated protein kinases have a principal role in upregulation of telomerase activity in $\mathrm{T}$ cells [41]. Interestingly, telomerase activity in $\mathrm{CD}^{+}$ $\mathrm{T}$ cells is much more than in $\mathrm{CD} 8^{+} \mathrm{T}$ cells, which could be the main reason for increasing $\mathrm{T} \mathrm{CD} 8^{+} 28^{-}$in aging [38]. Gharagozloo et al. studies on peripheral blood from $\beta$-thalassemia major patients have shown an increased level of premature senescence of T lymphocytes, T CD8+28- [42], which may be related to the oxidative stress condition of thalassemia. Moreover, a decrease in $\mathrm{CD}^{+}$cell circulation and expansion of $\mathrm{CD}^{+} 28^{-}$in peripheral blood of thalas- 
semia patients have been shown [43]. There are three main relevant proofs for shifting lymphocytes to the senescence state in $\beta$-thalassemia major:

1. TfR1 plays essential roles in lymphocyte development and activation. Expression of TfR downregulates in iron overload state due to coordination of messenger RNA-encoding proteins by iron regulatory proteins. Similarly, blockade of TfR expression inhibits entry of T cells into the $S$ phase of the cell cycle and abrogates DNA synthesis. Also, inhibition of TfR expression in $\mathrm{T}$ cells prevents cell cycle progression from $\mathrm{G} 1$ to $\mathrm{S}$ phase $[5,44]$.

2. Synthesis of ferritin, the main storage protein of iron, increases in iron overload condition and oxidizes in oxidative stress state and breaks down by proteasome, which cause liberation and enhancement of iron. Saturation of ferritin and presence of transferrin-bound iron are associated with enhanced iron uptake by lymphocytes, which inhibits proliferation of lymphocytes [44-46].

3. A high level of ROS for a prolonged period disturbs the cell cycle progression of most cells, which could be an explanation for proliferation arrest of T lymphocytes [47].

Iron overload also leads to natural killer (NK) cell dysfunction, impaired neutrophil cytotoxicity, changes in the ratio of $\mathrm{CD}^{+}$to $\mathrm{CD} 8^{+}$lymphocytes, impairs proliferative responses of helper and cytotoxic T cells and also affects MHC class II and intercellular adhesion molecule 1 [48, 49]. Furthermore, iron overload is associated with reduced phagocytic activity toward some fungi, such as Candida albicans and may also promote the growth of hepatitis $\mathrm{C}$ virus [50]. Therefore, iron overload and oxidative stress condition in $\beta$-thalassemia major may result in an impaired immune function.

\section{Characteristics of immunosenescence and immunological aging}

As outlined above, oxidative stress in $\beta$-thalassemia major has some effect on the immune system which increases $\mathrm{T} \mathrm{CD} 8^{+} 28^{-}$replicative senescence T-lymphocyte. Identical clonal population of CD28- $\mathrm{T}$ cells has shorter telomeres than other $\mathrm{CD} 28^{+} \mathrm{T}$ cells [36]. One obvious culprit is oxidative stress condition which can be a reason for DNA damage and telomerase shortening [51]. Similar to oxidative stress, prolonged activation of T cells, in chronic infections, and aging increase $\mathrm{T}$-cells replicative senescence or in other words, increase T-cells with a different function and proliferation inability. As mentioned before, senescence lymphocyte has been known by the loss of the CD28 marker, a well-known co-stimulatory molecule which serves as a marker for CD8 T-cells replicative senescence. CD28 has major roles during T-cells activation, proliferation and survival $[52,53]$. Besides the function and proliferation, $\mathrm{CD} 8{ }^{+} \mathrm{T}$ cells that lose expression of CD28, display several peculiar features including reduction in T-cells receptor diversity [54], suppressive effect on CD4 T cells activation and defective proliferation during antigen stimulation [55]. Normal $\mathrm{CD} 8^{+} \mathrm{T}$ cells have an essential role in the protective effects of $\mathrm{T}$ helper cells vaccination and are very effective in $\mathrm{T}$ helper cells responsiveness and activation; $\mathrm{T} \mathrm{CD} 8^{+} 28^{-}$cells reduce immune response to pathogens, new infections, viruses and $\mathrm{T}$ cell vaccines [54]. Expression of inhibitory killer immunoglobulin-like receptors of NK cells on T CD8 ${ }^{+} 28^{-}$cells can have inhibitory effects [56]. T CD $8^{+} 28^{-}$cells have a regulatory role in adaptive immunity, they convert dendritic cells (DCs) to tolerogen by decreasing the expression of the co-stimulatory molecule on DCs [57]. Another inhibitory factor of senescence T cell is TGF- $\beta$, a cytokine that has a regulatory effect on the immune system. Besides the inhibitory effects of $\mathrm{T} \mathrm{CD} 8^{+} 28^{-}$cells on $\mathrm{T}$ helper lymphocytes, presence of these cells can decrease production of the antibody [58]. Although, by the age of 80 and above, $50-60 \%$ of $\mathrm{CD}^{+} \mathrm{T}$ cells lack CD28 expression [35], a high proportion of $\mathrm{T} \mathrm{CD} 8^{+} 28^{-}$cells have been observed in some chronic viral infections such as HIV, cytomegalovirus and Epstein-Barr virus (EBV). T CD8 ${ }^{+} 28^{-}$cells specific for the virus increase in these patients [59] (Fig. 1), suggesting that chronic stimulation of the immune system preferentially induces a kind of immune inhibitory state or immunosenescence. T CD $8^{+} 28^{-}$cells are observed in old age humans and non-human primates but not in mice [56], so mice cannot be a model for old age human immune system with elevated T CD8 ${ }^{+} 28^{-}$cells. Presence of CD28$\mathrm{T}$ cells can be the reason for lower capacity to respond to new infections, environmental exposures, and vaccines in old ages $[54,60]$. It seems that augmentation of senescence $\mathrm{T}$ cells impairs the immune system function, and an increase in these cells in $\beta$-thalassemia major patients may explain an increased incidence of infections. Indeed, infection is directly responsible for $12-46 \%$ of morbidity in patients with $\beta$-thalassemia major [61]. Presence of senescence cells could have inhibitory effects on the immune system. In particular, they can compete for access to the antigen. Overall, the mechanism of action and their effects on the immune system has been poorly understood.

\section{Common points of chronic virus infection and thalassemia}

Human immunodeficiency virus increases intracellular free radicals by permanent activation and consequently, elevates markers of oxidative stress condition such as oxidized lipids, proteins, and DNA and reduces antioxidant. Besides permanent cell activation, virus proteins such as tat and GP120 cause oxidative stress and increase ROS production [62]. Also, it seems that HAART treatment has a pro-oxidant effect and promotes oxidative stress condition. Oxidative stress in HIV-positive patients increases virus replication and decreases antioxidant activity [63, 64]. Many studies have reported lack of antioxidants in 


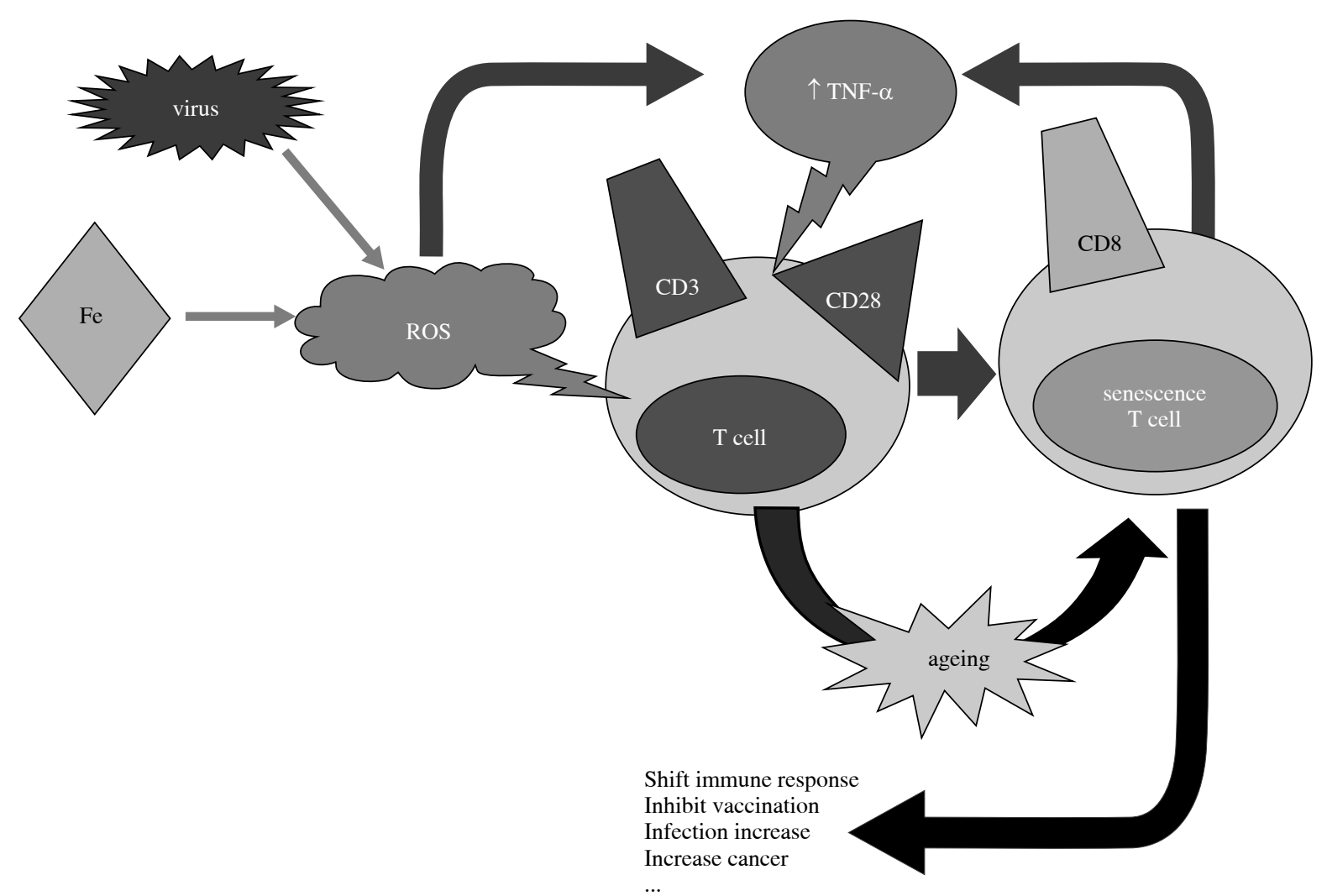

Fig. 1. Main reasons for generation of senescence cells, which result in immune dysfunction chronic infection and iron overload affect immune system $\mathrm{CD}^{+}$lymphocytes similar to aging. They cause senescence lymphocytes increase that lack CD28 marker. Senescence lymphocytes and ROS increase TNF- $\alpha$ production. TNF- $\alpha$ affect CD8 $8^{+}$lymphocytes and increase senescence cells, a positive feedback loop. Senescence cells shift immune response and adversely affect immune system

acquired immunodeficiency syndrome (AIDS) patients, which could be the reason for drug toxicity and deleterious effects on the immune system [65]. It seems that ROS production in oxidative stress condition in HIV infected individuals, remarkably decreases antioxidant enzymes and causes progression to AIDS $[63,66]$. Like $\beta$-thalassemia major, oxidative stress impairs phagocytic functions and enhances senescence T lymphocytes, $\mathrm{T} \mathrm{CD} 8^{+} 28^{-}$cells, in HIV-infected adults and children [67]. As it is expected, there is a positive correlation between $\mathrm{T} \mathrm{CD} 8^{+} 28^{-}$cells and rapid progression of the disease. Irrespective of the CD4 T cells number, HIV disease progresses faster to AIDS in aging people [68, 69], which could be due to the increment senescence $\mathrm{T}$ cells in aging. Oxidative stress also occurs in chronic liver disease. Hepatitis $\mathrm{C}$ virus $(\mathrm{HCV})$ contains core proteins and non-structural proteins, which cause oxidative stress. Oxidative stress markers such as ROS, oxidized lipid and serum hydroperoxides increase in hepatitis C. Also the antioxidants level decreases in liver and blood of HCV infected individuals. Similar to thalassemia, iron overload has been found in this disease and severe hepatitis and fibrosis correlate with the serum iron level [70-72]. With regard to the oxidative stress, ROS marker levels significantly increase in HCV patients in comparison with normal controls [73]. Mitochondria and cytochrome P450 enzymes of Kupffer cells and neutrophils produce ROS in hepatocytes in acute or chronic liver disease [74]. In addition to the ROS, low levels of hTERT mRNA expression have been shown in chronic viral hepatitis [75]. In HCV infected individuals, ROS increase in lymphocytes of patients is remarkable. Also, enhanced senescence $\mathrm{T} \mathrm{CD} 8^{+} 28^{-}$has been found in chronic hepatitis $\mathrm{C}$ condition $[76,77]$. EBV is the major agent in the pathogenesis of a variety of lymphomas. EBV products include six EBV nuclear antigens (EBNA1, 2, 3A, 3B, 3C and LP), three latent membrane proteins (LMP1, 2A, 2B), two non-translated RNAs (EBER1 and EBER2) and several microRNAs. EBNA1 is common in all EBV-associated malignancies and cause telomere uncapping, is a common cause of DNA damage at telomeres, and DNA breakage at telomeres [78-80]. $\mathrm{T} \mathrm{CD}^{+}$cells specific for EBV have shorter telomeres than other $\mathrm{T}$ cells and senescence CD8 ${ }^{+}$ $\mathrm{T}$ cells also increase in EBV infected individuals [81, 82]. These data are consistent with previous studies indicating chronic EBV infection drives EBV specific CD8 T cells towards differentiated phenotypes. 


\section{Oxidative stress and tumor necrosis factor $\alpha$}

Oxidative stress increases tumor necrosis factor $\alpha$ $(\mathrm{TNF}-\alpha)$ via nuclear factor $\kappa \mathrm{B}(\mathrm{NF}-\kappa \mathrm{B})$ activation, subject of an excellent review (Fig. 1). Indeed, ROS releases $\mathrm{I} \kappa \mathrm{B}$, an inhibitory factor of $\mathrm{NF}-\kappa \mathrm{B}$, and activates $\mathrm{NF}-\kappa \mathrm{B}$ to translocate into the nucleus. Oxidative stress and TNF- $\alpha$ are induced by HIV-1 tat [83] and TNF- $\alpha$ can also induce HIV expression in monocytic cells. TNF- $\alpha$ induces a significant quantitative reduction in CD28 molecules on the cell surface which leads to the genesis of CD28- T cells. Besides ROS, senescence cells increase production of proinflammatory cytokines such as TNF- $\alpha[84,85]$. Surprisingly, TNF- $\alpha$ increases in HIV, EBV, HCV and $\beta$-thalassemia major patients and an elevated level of TNF- $\alpha$ provokes a decreased expression of CD28 [86-89].

\section{Antioxidant therapy in chronic virus infection and $\beta$-thalassemia major}

\section{Natural antioxidant}

Glutathione (GSH) is the major thiol (non-enzymatic) intracellular antioxidant which decreases in oxidative stress condition [90]. GSH synthesis is repressed in HIV infection. Generation of ROS in HIV-infected individuals results in disruption in GSH metabolism [91]. Non-enzymatic antioxidants such as GSH, vitamins C, E and A, and activity of enzymatic antioxidants such as catalase, superoxide dismutase (SOD), GSH peroxidase (GPx) and GSH s-transferase, considerably decrease in HIV/AIDS [92]. Also, formation of ROS results in decreasing CD4 counts in HIV patients. Gamma glutamyl transferase is the major enzyme for GSH metabolism in cells [93]. GPx is a selenocysteine enzyme which protects cells from endogenous peroxides, modulates the respiratory burst and reduces superoxide production. Decreasing GSH by $10 \%$ to $40 \%$ in lymphocytes can completely inhibit activation and GSH depletion adversely affects immunological functions and viral clearance [94]. It seems that oxidative stress is the major mechanism in the progression of HIV [95]. Therefore, antioxidant agents can bring back the immune function and slow the progression to AIDS [96]. GSH also inhibits NF$\kappa \mathrm{B}$ by scavenging free radicals within the cytosol [90]. The level of GSH in peripheral blood mononuclear cells (PB$\mathrm{MCs}$ ) of thalassemia major patients is very low. Restoration of GSH levels could increase PBMC proliferation [97].

\section{Selenium}

Selenium is an essential element for biosynthesis of GSH contents. Selenium deficiency has an adverse effect on cellular and humoral immunity. Selenium with other antioxidants such as vitamin $\mathrm{E}$ is more involved in preventing free radicals production. Selenium compounds reduce oxidative damage to biomolecules such as DNA and scavenge free radicals, and repair molecular damage sites [98]. Lack of selenium is related to a decrease in GSH peroxidase activity in HIV-infected individuals which underlies tissue injury by ROS. In HIV, alterations of antioxidant enzymes due to oxidative stress decrease antioxidant defense. Thus, accumulation of selenium can potentiate some antioxidant enzymes' effect against free radicals and inhibit HIV replication [99]. Selenium deficiency results in faster progression of the disease in HIV patients [64]. Selenium seems to be a crucial nutrient for HIV-infected individuals and is a potent inhibitor of HIV replication in vitro [100]. Also, a progressive decline in plasma selenium has been associated with persistent loss of CD4 T cells in HIV infection [101]. Selenium-deficiency is indicative of a poor prognosis in HIV-positive patients. They are nearly 20 times more susceptible to die from HIV-related causes [102]. Indeed, a lower level of selenium in HIV-infected patients decrease the numbers and functions of circulating $\mathrm{CD}^{+} \mathrm{T}$ cells profoundly [103]. Selenium also has a protective role in individuals infected with $\mathrm{HCV}$ against the progression to cancer [104].

\section{Zinc}

Zinc (Zn) deficiency adversely affects the immunological function. It causes an imbalance between Th1 and Th2 functions, cytokine production and decreases $\mathrm{T}$ cells counts [105]. $\mathrm{Zn}$ is an antioxidant that can restore immune functions and increase $\mathrm{CD}^{+} \mathrm{T}$ cells count in AIDS and inhibit the incidence of opportunistic infections in AIDS patients. It increases neutrophil functions and cytokine production (IL-1, IL-6, TNF- $\alpha$, IFN- $\alpha$ ) in PBMCs [106]. HCV-induced oxidative stress increases oxidized GSH [107]. Also, GSH production increases PBMCs [108] but levels of vitamins C, $\mathrm{B}$, and $\mathrm{E}$ and activity of SOD and catalase and SOD are low in HCV infected individuals [109, 110]. $\mathrm{Zn}$ is involved in SODs and enzymes and protects from lipid peroxidation. $\mathrm{Zn}$ has a synergistic effect with other antioxidants. Zn supplements significantly improve the liver function [111].

\section{Vitamins}

Vitamin E acts as an antioxidant on biomembranes and prevents lipid peroxidation more effectively than selenium. Actually, selenium has the major role for scavenging free radicals. Vitamin $\mathrm{E}$ is the principal lipid soluble, chain breaking antioxidant in mitochondria, microsomes, and lipoproteins. Vitamin E can reduce ROS in lymphocytes of $\beta$-thalassemia patients [112]. Vitamin C is a water soluble vitamin which neutralizes water soluble radicals and protects cell components from free radical damage and reduces lipid peroxidation derivatives [113]. HIV-infected individuals have a low level of vitamins C and $\mathrm{E}$, which may be due to oxidative stress which increases demand in the detoxification/neutralization of free radicals or malabsorption and diarrhea that are common complications of AIDS [63]. Remarkably, levels of vitamins $\mathrm{A}, \mathrm{C}$ and $\mathrm{E}$, especially vitamin $\mathrm{E}$, in HIV-positive 
adult or pediatric patients are low [114-116]. Vitamin E also inhibits $\mathrm{H}_{2} \mathrm{O}_{2}$ production in EBV infection [117]. Vitamin A deficiency has been shown to induce oxidative stress [118]. Oxidative stress and a lower level of antioxidant agents have also been seen in pediatric patients with acute hepatitis A $[119,120]$. Concentrations of vitamin E and $\mathrm{Zn}$ and levels of antioxidant enzymes GPx and SOD are significantly low in $\beta$-thalassemia patients. Antioxidants like silymarin, a flavonolignan complex isolated from milk thistle, can boost the immune system function and also decrease TNF- $\alpha$ in these patients [121, 122]. Maybe, antioxidant supplements normalize the immune dysfunction in oxidative stress condition [123, 124].

\section{Conclusions}

A survey of the immune system of old age is really necessary for vaccination of old ages, and age related diseases, which is one of the greatest government problems. However, oxidative stress is responsible for many old age related diseases [125-127]. In addition, air pollutants, modern life style and diet have made immune system senescence faster than in the past; however, there is a strong correlation between cancer and immunosenescence. Oxidative stress could be a reason for old age diseases such as Alzheimer's disease and Parkinson's disease and has an important role in autoimmune diseases such as systemic lupus erythematous [128, 129]. Besides, because of chronic iron overload in thalassemia major patients, chronic oxidative stress can be the reason for immunosenescence. Physiologic conditions of these patients can make them a human model for immunosenescence. Also, iron overload occurs in other diseases such as haemodialysed (HD) uremic patients, who receive iron intravenously. HD patients have defects in $\mathrm{NK}$ and $\mathrm{T}$ cell division and function. Immunosenescence features have been poorly understood. Therapeutic interventions which change senescence cell behavior are very useful for treatment in age related diseases, chronic virus infections and any conditions that increase these cells. Antioxidant therapy can be really effective for the immune system function in oxidative stress conditions. Selective elimination of these cells represents a new way to improve the immune system. It will reveal strategies to boost the immune system. A study of the immune system in thalassemia patients may identify more characteristics of the immune system senescence cells. It may also explain why the elevated level of NTBI increases the risk of bacterial and fungal infections and rapid leukemic progression more specifically. In addition, further studies need to define the phenotypic character of senescence lymphocyte such as the amount of P53, telomere length, DNA damage percentage, levels of the ROS and expression of surface markers including CD57 and CD100 in thalassemia patients. Because of the chronic oxidative state in these patients, investigation of old age diseases relevant to the immune system can be useful. In conclusion, understanding the immune system of thalassemia patients can increase our knowledge of aging, vaccination of old age and changes in the immune system, which also occur in chronic virus infections. Also, it may promote new insights for improving the quality of life of major thalassemia patients through developing new therapies.

This work was funded by the Deputy of Research and Technology of Shahrekord University of Medical Sciences. We also thank all who have contributed, in some way, to this research.

The authors declare no conflict of interest.

\section{References}

1. Politou M, Kalotychou V, Pissia M, et al. (2004): The impact of the mutations of the HFE gene and of the SLC11A3 gene on iron overload in Greek thalassemia intermedia and beta(s)/ beta(thal) anemia patients. Haematologica 89: 490-492.

2. Rachmilewitz EA, Weizer-Stern O, Adamsky K, et al. (2005): Role of iron in inducing oxidative stress in thalassemia: Can it be prevented by inhibition of absorption and by antioxidants? Ann N Y Acad Sci 1054: 118-123.

3. Kakhlon O, Cabantchik ZI (2002): The labile iron pool: characterization, measurement, and participation in cellular processes. Free Radic Biol Med 33: 1037-1046.

4. Breuer W, Hershko C, Cabantchik ZI (2002): The importance of non-transferrin bound iron in disorders of iron metabolism. Transfus Sci 23: 185-192.

5. Aisen P, Enns C, Wessling-Resnick M (2001): Chemistry and biology of eukaryotic iron metabolism. Int J Biochem Cell Biol 33: 940-959.

6. Esposito BP, Breuer W, Sirankapracha P, et al. (2003): Labile plasma iron in iron overload: redox activity and susceptibility to chelation. Blood 102: 2670-2677.

7. Farina M, Avila DS, da Rocha JB, Aschner M (2013): Metals, oxidative stress and neurodegeneration: a focus on iron, manganese and mercury. Neurochem Int 62: 575-594.

8. Cighetti G, Duca L, Bortone L, et al. (2002): Oxidative status and malondialdehyde in beta-thalassaemia patients. Eur J Clin Invest 32 Suppl 1: 55-60.

9. Campanella A, Rovelli E, Santambrogio P, et al. (2009): Mitochondrial ferritin limits oxidative damage regulating mitochondrial iron availability: hypothesis for a protective role in Friedreich ataxia. Hum Mol Genet 18: 1-11.

10. Nunez MT, Urrutia P, Mena N, et al. (2012): Iron toxicity in neurodegeneration. Biometals 25: 761-776.

11. Brissot P, Ropert M, Le Lan C, Loreal O (2012): Non-transferrin bound iron: a key role in iron overload and iron toxicity. Biochim Biophys Acta 1820: 403-410.

12. Porter JB, Garbowski M (2014): The pathophysiology of transfusional iron overload. Hematol Oncol Clin North Am 28: 683-701.

13. Wu D, Cederbaum AI. Alcohol, oxidative stress, and free radical damage. Alcohol Res Health 2003; 27: 277-284.

14. Walter PB, Fung EB, Killilea DW, et al. (2006): Oxidative stress and inflammation in iron-overloaded patients with beta-thalassaemia or sickle cell disease. Br J Haematol 135: 254-263.

15. Scott $\mathrm{MD}$ (2006): $\mathrm{H}_{2} \mathrm{O}_{2}$ injury in beta thalassemic erythrocytes: protective role of catalase and the prooxidant effects of GSH. Free Radic Biol Med 40: 1264-1272. 
16. Meral A, Tuncel P, Surmen-Gur E, et al. (2000): Lipid peroxidation and antioxidant status in beta-thalassemia. Pediatr Hematol Oncol 17: 687-693.

17. Roy N, Stoyanova T, Dominguez-Brauer C, et al. (2010): DDB2, an essential mediator of premature senescence. Mol Cell Biol 30: 2681-2692.

18. Shay JW, Wright WE (2000): Hayflick, his limit, and cellular ageing. Nat Rev Mol Cell Biol 1: 72-76.

19. Bekaert S, De Meyer T, Van Oostveldt P (2005): Telomere attrition as ageing biomarker. Anticancer Res 25: 3011-3021.

20. Sitte N, Merker K, Von Zglinicki T, et al. (2000): Protein oxidation and degradation during cellular senescence of human BJ fibroblasts: part II - aging of nondividing cells. FASEB J 14: 2503-2510.

21. Serrano M, Blasco MA (2001): Putting the stress on senescence. Curr Opin Cell Biol 13: 748-753.

22. Samani KG, Farrokhi E (2014): Effects of cumin extract on oxLDL, paraoxanase 1 activity, FBS, total cholesterol, triglycerides, HDL-C, LDL-C, Apo A1, and Apo B in in the patients with hypercholesterolemia. Int J Health Sci (Qassim) 8: 39.

23. Parrinello S, Samper E, Krtolica A, et al. (2003): Oxygen sensitivity severely limits the replicative lifespan of murine fibroblasts. Nat Cell Biol 5: 741-747.

24. Kawanishi S, Hiraku Y, Oikawa S (2001): Mechanism of guanine-specific DNA damage by oxidative stress and its role in carcinogenesis and aging. Mutat Res 488: 65-76.

25. Hamilton ML, Van Remmen H, Drake JA, et al. (2001): Does oxidative damage to DNA increase with age? Proc Natl Acad Sci U S A 98: 10469-10474.

26. Toussaint O, Medrano EE, von Zglinicki T (2000): Cellular and molecular mechanisms of stress-induced premature senescence (SIPS) of human diploid fibroblasts and melanocytes. Exp Gerontol 35: 927-945.

27. Frippiat C, Dewelle J, Remacle J, Toussaint O (2002): Signal transduction in $\mathrm{H} 2 \mathrm{O} 2$-induced senescence-like phenotype in human diploid fibroblasts. Free Radic Biol Med 33: 1334-1346.

28. Kahlem P, Dorken B, Schmitt CA (2004): Cellular senescence in cancer treatment: friend or foe? J Clin Invest 113: 169-174.

29. Duan J, Duan J, Zhang Z, Tong T (2005): Irreversible cellular senescence induced by prolonged exposure to $\mathrm{H} 2 \mathrm{O} 2$ involves DNA-damage-and-repair genes and telomere shortening. Int J Biochem Cell Biol 37: 1407-1420.

30. Deicher R, Ziai F, Cohen G, et al. (2003): High-dose parenteral iron sucrose depresses neutrophil intracellular killing capacity. Kidney Int 64: 728-736.

31. Kuo KL, Hung SC, Wei YH, Tarng DC (2008): Intravenous iron exacerbates oxidative DNA damage in peripheral blood lymphocytes in chronic hemodialysis patients. J Am Soc Nephrol 19: 1817-1826.

32. Effros RB (2000): Long-term immunological memory against viruses. Mech Ageing Dev 121: 161-171.

33. Effros RB, Boucher N, Porter V, et al. (1994): Decline in $\mathrm{CD} 28+\mathrm{T}$ cells in centenarians and in long-term T cell cultures: a possible cause for both in vivo and in vitro immunosenescence. Exp Gerontol 29: 601-609.

34. Spaulding C, Guo W, Effros RB (1999): Resistance to apoptosis in human CD8+ T cells that reach replicative senescence after multiple rounds of antigen-specific proliferation. Exp Gerontol 34: 633-644.

35. Fagnoni FF, Vescovini R, Mazzola M, et al. (1996): Expansion of cytotoxic CD8+ CD28- T cells in healthy ageing people, including centenarians. Immunology 88: 501-507.
36. Monteiro J, Batliwalla F, Ostrer H, Gregersen PK (1996): Shortened telomeres in clonally expanded CD28-CD8+ $\mathrm{T}$ cells imply a replicative history that is distinct from their CD28+CD8+ counterparts. J Immunol 156: 3587-3590.

37. Weng NP, Hathcock KS, Hodes RJ (1998): Regulation of telomere length and telomerase in T and B cells: a mechanism for maintaining replicative potential. Immunity 9: 151-157.

38. Valenzuela VF, Effros RB (2002): Divergent telomerase and CD28 expression patterns in human CD4 and CD8 T cells following repeated encounters with the same antigenic stimulus. Clin Immunol 105: 117-125.

39. Plunkett FJ, Franzese O, Finney HM, et al. (2007): The loss of telomerase activity in highly differentiated CD8+CD28-CD27T cells is associated with decreased Akt (Ser473) phosphorylation. J Immunol 178: 7710-7719.

40. Jacinto E, Facchinetti V, Liu D, et al. (2006): SIN1/MIP1 maintains rictor-mTOR complex integrity and regulates Akt phosphorylation and substrate specificity. Cell 127: 125-137.

41. Fauce SR, Jamieson BD, Chin AC, et al. (2008): Telomerase-based pharmacologic enhancement of antiviral function of human CD8+ T lymphocytes. J Immunol 181: 7400-7406.

42. Gharagozloo M, Bagherpour B, Tahanian M, et al. (2009): Premature senescence of $\mathrm{T}$ lymphocytes from patients with beta-thalassemia major. Immunol Lett 122: 84-88.

43. Gupta A, Zhuo J, Zha J, et al. (2010): Effect of different intravenous iron preparations on lymphocyte intracellular reactive oxygen species generation and subpopulation survival. BMC Nephrol 11: 16.

44. Hentze MW, Muckenthaler MU, Andrews NC (2004): Balancing acts: molecular control of mammalian iron metabolism. Cell 117: 285-297.

45. Rudeck M, Volk T, Sitte N, Grune T (2000): Ferritin oxidation in vitro: implication of iron release and degradation by the $20 \mathrm{~S}$ proteasome. IUBMB Life 49: 451-456.

46. Djeha A, Brock JH (1992): Uptake and intracellular handling of iron from transferrin and iron chelates by mitogen stimulated mouse lymphocytes. Biochim Biophys Acta 1133: 147-152.

47. Nakazawa H, Genka C, Fujishima M (1996): Pathological aspects of active oxygens/free radicals. Jpn J Physiol 46: 15-32.

48. Mencacci A, Cenci E, Boelaert JR, et al. (1997): Iron overload alters innate and $\mathrm{T}$ helper cell responses to Candida albicans in mice. J Infect Dis 175: 1467-1476.

49. Cardier JE, Romano E, Soyano A (1997): T lymphocytes subsets in experimental iron overload. Immunopharmacol Immunotoxicol 19: 75-87.

50. Rubin RB, Barton AL, Banner BF, Bonkovsky HL (1995): Iron and chronic viral hepatitis: emerging evidence for an important interaction. Dig Dis 13: 223-238.

51. Saretzki G, Von Zglinicki T (2002): Replicative aging, telomeres, and oxidative stress. Ann N Y Acad Sci 959: 24-29.

52. Jiang H, Braunstein NS, Yu B, et al. (2001): CD8+ T cells control the TH phenotype of MBP-reactive CD4+ T cells in EAE mice. Proc Natl Acad Sci U S A 98: 6301-6306.

53. Saurwein-Teissl M, Lung TL, Marx F, et al. (2002): Lack of antibody production following immunization in old age: association with CD8(+)CD28(-) T cell clonal expansions and an imbalance in the production of Th1 and Th2 cytokines. J Immunol 168: 5893-5899.

54. Goronzy JJ, Fulbright JW, Crowson CS, et al. (2001): Value of immunological markers in predicting responsiveness to influenza vaccination in elderly individuals. J Virol 75: 1218212187. 
55. Ciubotariu R, Colovai AI, Pennesi G, et al. (1998): Specific suppression of human CD4+ Th cell responses to pig MHC antigens by CD8+CD28- regulatory T cells. J Immunol 161: 5193-5202.

56. Henel G, Singh K, Cui D, et al. (2006): Uncoupling of T-cell effector functions by inhibitory killer immunoglobulin-like receptors. Blood 107: 4449-4457.

57. Fann M, Chiu WK, Wood WH, et al. (2005): Gene expression characteristics of CD28null memory phenotype CD8+ $\mathrm{T}$ cells and its implication in T-cell aging. Immunol Rev 205: 190-206.

58. Najafian N, Chitnis T, Salama AD, et al. (2003): Regulatory functions of $\mathrm{CD} 8+\mathrm{CD} 28-\mathrm{T}$ cells in an autoimmune disease model. J Clin Invest 112: 1037-1048.

59. Dock JN, Effros RB (2011): Role of CD8 T Cell Replicative Senescence in Human Aging and in HIV-mediated Immunosenescence. Aging Dis 2: 382-397.

60. Goodwin K, Viboud C, Simonsen L (2006): Antibody response to influenza vaccination in the elderly: a quantitative review. Vaccine 24: 1159-1169.

61. Borgna-Pignatti C, Rugolotto S, De Stefano P, et al. (1998): Survival and disease complications in thalassemia major. Ann N Y Acad Sci 850: 227-231.

62. Aksenov MY, Hasselrot U, Bansal AK, et al. (2001): Oxidative damage induced by the injection of HIV-1 Tat protein in the rat striatum. Neurosci Lett 305: 5-8.

63. Suresh DR, Annam V, Pratibha K, Prasad BV (2009): Total antioxidant capacity - a novel early bio-chemical marker of oxidative stress in HIV infected individuals. J Biomed Sci 16: 61.

64. Sundaram M, Saghayam S, Priya B, et al. (2008): Changes in antioxidant profile among HIV-infected individuals on generic highly active antiretroviral therapy in southern India. Int J Infect Dis 12: e61-66.

65. Ngondi JL, Oben J, Forkah DM, et al. (2006): The effect of different combination therapies on oxidative stress markers in HIV infected patients in Cameroon. AIDS Res Ther 3: 19.

66. Mandas A, Iorio EL, Congiu MG, et al. (2009): Oxidative imbalance in HIV-1 infected patients treated with antiretroviral therapy. J Biomed Biotechnol 2009: 749575.

67. Kaplan RC, Sinclair E, Landay AL, et al. (2011): T cell activation and senescence predict subclinical carotid artery disease in HIV-infected women. J Infect Dis 203: 452-463.

68. Kirkham P (2007): Oxidative stress and macrophage function: a failure to resolve the inflammatory response. Biochem Soc Trans 35: 284-287.

69. Carre N, Deveau C, Belanger F, et al. (1994): Effect of age and exposure group on the onset of AIDS in heterosexual and homosexual HIV-infected patients. SEROCO Study Group. AIDS 8: 797-802.

70. Parola M, Robino G (2001): Oxidative stress-related molecules and liver fibrosis. J Hepatol 35: 297-306.

71. Valgimigli M, Valgimigli L, Trere D, et al. (2002): Oxidative stress EPR measurement in human liver by radical-probe technique. Correlation with etiology, histology and cell proliferation. Free Radic Res 36: 939-948.

72. Lopez-Prieto J, Gonzalez-Reimers E, Aleman-Valls MR, et al. (2013): Iron and proinflammatory cytokines in chronic hepatitis $C$ virus infection. Biol Trace Elem Res 155: 5-10.

73. Venturini D, Simao AN, Barbosa DS, et al. (2010): Increased oxidative stress, decreased total antioxidant capacity, and iron overload in untreated patients with chronic hepatitis C. Dig Dis Sci 55: 1120-1127.
74. Kundu D, Roy A, Mandal T, et al. (2012): Oxidative stress in alcoholic and viral hepatitis. N Am J Med Sci 4: 412-415.

75. Satra M, Dalekos GN, Kollia P, et al. (2005): Telomerase reverse transcriptase mRNA expression in peripheral lymphocytes of patients with chronic $\mathrm{HBV}$ and $\mathrm{HCV}$ infections. J Viral Hepat 12: 488-493.

76. Bhargava A, Raghuram GV, Pathak N, et al. (2011): Occult hepatitis $\mathrm{C}$ virus elicits mitochondrial oxidative stress in lymphocytes and triggers PI3-kinase-mediated DNA damage response. Free Radic Biol Med 51: 1806-1814.

77. Manfras BJ, Weidenbach H, Beckh KH, et al. (2004): Oligoclonal CD8+ T-cell expansion in patients with chronic hepatitis $\mathrm{C}$ is associated with liver pathology and poor response to interferon-alpha therapy. J Clin Immunol 24: 258-271.

78. Young LS, Rickinson AB (2004): Epstein-Barr virus: 40 years on. Nat Rev Cancer 4: 757-768.

79. Xia T, O'Hara A, Araujo I, et al. (2008): EBV microRNAs in primary lymphomas and targeting of CXCL-11 by ebv-mirBHRF1-3. Cancer Res 68: 1436-1442.

80. Kamranvar SA, Masucci MG (2011): The Epstein-Barr virus nuclear antigen-1 promotes telomere dysfunction via induction of oxidative stress. Leukemia 25: 1017-1025.

81. Petrova M, Muhtarova M, Nikolova M, et al. (2006): Chronic Epstein-Barr virus-related hepatitis in immunocompetent patients. World J Gastroenterol 12: 5711-5716.

82. Weng NP, Akbar AN, Goronzy J (2009): CD28(-) T cells: their role in the age-associated decline of immune function. Trends Immunol 30: 306-312.

83. Shi B, Raina J, Lorenzo A, et al. (1998): Neuronal apoptosis induced by HIV-1 Tat protein and TNF-alpha: potentiation of neurotoxicity mediated by oxidative stress and implications for HIV-1 dementia. J Neurovirol 4: 281-290.

84. Eylar EH, Lefranc CE, Yamamura Y, et al. (2001): HIV infection and aging: enhanced Interferon- and Tumor Necrosis Factor-alpha production by the $\mathrm{CD} 8+\mathrm{CD} 28-\mathrm{T}$ subset. BMC Immunol 2: 10.

85. Zanni F, Vescovini R, Biasini C, et al. (2003): Marked increase with age of type 1 cytokines within memory and effector/cytotoxic CD8+ T cells in humans: a contribution to understand the relationship between inflammation and immunosenescence. Exp Gerontol 38: 981-987.

86. Olofsson PS (2012): Targeting T cell costimulation to prevent atherothrombosis. Circ Res 110: 800-801.

87. Butthep P, Rummavas S, Wisedpanichkij R, et al. (2002): Increased circulating activated endothelial cells, vascular endothelial growth factor, and tumor necrosis factor in thalassemia. Am J Hematol 70: 100-106.

88. Glaser R, Litsky ML, Padgett DA, et al. (2006): EBV-encoded dUTPase induces immune dysregulation: Implications for the pathophysiology of EBV-associated disease. Virology 346: 205-218.

89. Crespo J, Rivero M, Fabrega E, et al. (2002): Plasma leptin and TNF-alpha levels in chronic hepatitis $\mathrm{C}$ patients and their relationship to hepatic fibrosis. Dig Dis Sci 47: 1604-1610.

90. Biswas SK, McClure D, Jimenez LA, et al. (2005): Curcumin induces glutathione biosynthesis and inhibits NF-kappaB activation and interleukin- 8 release in alveolar epithelial cells: mechanism of free radical scavenging activity. Antioxid Redox Signal 7: 32-41.

91. Muller F, Svardal AM, Nordoy I, et al. (2000): Virological and immunological effects of antioxidant treatment in patients with HIV infection. Eur J Clin Invest 30: 905-914. 
92. Favier A, Sappey C, Leclerc P, et al. (1994): Antioxidant status and lipid peroxidation in patients infected with HIV. Chem Biol Interact 91: 165-180.

93. Kugelman A, Choy HA, Liu R, et al. (1994): Gamma-Glutam$\mathrm{yl}$ transpeptidase is increased by oxidative stress in rat alveolar L2 epithelial cells. Am J Respir Cell Mol Biol 11: 586-592.

94. Staal FJ, Ela SW, Roederer M, et al. (1992): Glutathione deficiency and human immunodeficiency virus infection. Lancet 339: 909-912.

95. Steiner J, Haughey N, Li W, et al. (2006): Oxidative stress and therapeutic approaches in HIV dementia. Antioxid Redox Signal 8: 2089-2100.

96. Hurwitz BE, Klaus JR, Llabre MM, et al. (2007): Suppression of human immunodeficiency virus type 1 viral load with selenium supplementation: a randomized controlled trial. Arch Intern Med 167: 148-154.

97. Alidoost F, Gharagozloo M, Bagherpour B, et al. (2006): Effects of silymarin on the proliferation and glutathione levels of peripheral blood mononuclear cells from beta-thalassemia major patients. Int Immunopharmacol 6: 1305-1310.

98. Neve J (1996): Selenium as a risk factor for cardiovascular diseases. J Cardiovasc Risk 3: 42-47.

99. Rayman MP (2000): The importance of selenium to human health. Lancet 356: 233-241.

100. Sappey C, Legrand-Poels S, Best-Belpomme M, et al. (1994): Stimulation of glutathione peroxidase activity decreases HIV type 1 activation after oxidative stress. AIDS Res Hum Retroviruses 10: 1451-1461.

101. Look MP, Rockstroh JK, Rao GS, et al. (1997): Serum selenium versus lymphocyte subsets and markers of disease progression and inflammatory response in human immunodeficiency virus-1 infection. Biol Trace Elem Res 56: 31-41.

102. Campa A, Shor-Posner G, Indacochea F, et al. (1999): Mortality risk in selenium-deficient HIV-positive children. J Acquir Immune Defic Syndr Hum Retrovirol 20: 508-513.

103. Ammann AJ, Abrams D, Conant M, et al. (1983): Acquired immune dysfunction in homosexual men: immunologic profiles. Clin Immunol Immunopathol 27: 315-325.

104. Brigelius-Flohe R, Banning A (2006): Part of the series: from dietary antioxidants to regulators in cellular signaling and gene regulation. Sulforaphane and selenium, partners in adaptive response and prevention of cancer. Free Radic Res 40: 775-787.

105. Prasad AS (1996): Zinc: the biology and therapeutics of an ion. Ann Intern Med 125: 142-144.

106. Wellinghausen N, Kirchner H, Rink L (1997): The immunobiology of zinc. Immunol Today 18: 519-521.

107. Barbaro G, Di Lorenzo G, Ribersani M, et al. (1999): Serum ferritin and hepatic glutathione concentrations in chronic hepatitis $\mathrm{C}$ patients related to the hepatitis $\mathrm{C}$ virus genotype. J Hepatol 30: 774-782.

108. Boya P, de la Pena A, Beloqui O, et al. (1999): Antioxidant status and glutathione metabolism in peripheral blood mononuclear cells from patients with chronic hepatitis C. J Hepatol 31: 808-814.

109. Lin CC, Liu WH, Wang ZH, Yin MC (2011): Vitamins B status and antioxidative defense in patients with chronic hepatitis B or hepatitis C virus infection. Eur J Nutr 50: 499-506.

110. Yadav D, Hertan HI, Schweitzer P, et al. (2002): Serum and liver micronutrient antioxidants and serum oxidative stress in patients with chronic hepatitis C. Am J Gastroenterol 97: 2634-2639.

111. Chvapil M (1976): Effect of zinc on cells and biomembranes. Med Clin North Am 60: 799-812.
112. Pfeifer W, Degasperi G, Almeida M, et al. (2008): Vitamin E supplementation reduces oxidative stress in beta thalassaemia intermedia. Acta Haematol 120: 225-231.

113. Villalba JM, Navarro F, Gomez-Diaz C, et al. (1997): Role of cytochrome b5 reductase on the antioxidant function of coenzyme Q in the plasma membrane. Mol Aspects Med 18 Suppl: S7-13.

114. Bilbis LS, Idowu DB, Saidu Y, et al. (2010): Serum levels of antioxidant vitamins and mineral elements of human immunodeficiency virus positive subjects in Sokoto, Nigeria. Ann Afr Med 9: 235-239.

115. Djinhi J, Tiahou G, Zirihi G, et al. (2009): Selenium deficiency and oxidative stress in asymptomatic HIV1-infected patients in Cote d'Ivoire. Bull Soc Pathol Exot 102: 11-13.

116. Srinivas A, Dias BF (2008): Antioxidants in HIV positive children. Indian J Pediatr 75: 347-350.

117. Chen C, Reddy KS, Johnston TD, et al. (2003): Vitamin E inhibits cyclosporin $\mathrm{A}$ and $\mathrm{H} 2 \mathrm{O} 2$ promoted Epstein-Barr virus (EBV) transformation of human B cells as assayed by EBV oncogene LMP1 expression. J Surg Res 113: 228-233.

118. Chiu HJ, Fischman DA, Hammerling U (2008): Vitamin A depletion causes oxidative stress, mitochondrial dysfunction, and PARP-1-dependent energy deprivation. FASEB J 22: 3878-3887.

119. Kassab-Chekir A, Laradi S, Ferchichi S, et al. (2003): Oxidant, antioxidant status and metabolic data in patients with beta-thalassemia. Clin Chim Acta 338: 79-86.

120. Waseem F, Khemomal KA, Sajid R (2011): Antioxidant status in beta thalassemia major: a single-center study. Indian J Pathol Microbiol 54: 761-763.

121. Gharagozloo M, Karimi M, Amirghofran Z (2013): Immunomodulatory effects of silymarin in patients with beta-thalassemia major. Int Immunopharmacol 16: 243-247.

122. 122. Bahmani M, Shirzad H, Rafieian S, Rafieian-Kopaei M (2015): Silybum marianum: Beyond Hepatoprotection. J Evid Based Complementary Altern Med 20: 292-301.

123. Nasri H, Baradaran A, Shirzad H, Rafieian-Kopaei M (2014): New concepts in nutraceuticals as alternative for pharmaceuticals. Int J Prev Med 5: 1487-1499.

124. Asadi-Samani M, Kafash-Farkhad N, Azimi N, et al. (2015): Medicinal plants with hepatoprotective activity in Iranian folk medicine. Asian Pac J Trop Biomed 5: 146-157.

125. Niknam S, Ghatreh-Samani K, Farrokhi E (2015): The effect of adiponectin on osteonectin gene expression by oxidized low density lipoprotein-treated vascular smooth muscle cells. Int J Mol Cell Med Winter 4: 60-66.

126. Farrokhi E, Ghatreh Samani K, Hashemzadeh Chaleshtori M, Tabatabaiefar MA (2015): Effect of oxidized low density lipoprotein on the expression of Runx 2 and SPARC genes in vascular smooth muscle cells. Iran Biomed J 19: 160-164.

127. Nasri H, Shirzad H, Baradaran A, Rafieian-kopaei M (2015): Antioxidant plants and diabetes mellitus. J Res Med Sci 20: 491-502.

128. Bakhshalizadeh S, Esmaeili F, Houshmand F, et al. (2011): Effects of selegiline, a monoamine oxidase B inhibitor, on differentiation of P19 embryonal carcinoma stem cells, into neuron-like cells. In Vitro Cell Dev Biol Anim 47: 550-557.

129. Sarrafchi A, Bahmani M, Shirzad H, Rafieian-Kopaei M (2015): Oxidative stress and Parkinson's disease: New hopes in treatment with herbal antioxidants. Curr Pharm Des [Epub ahead of print]. 